\title{
Rio review to rejuvenate green initiatives
}

[WASHINGTON] Environmentalists are planning to use this year's fifth anniversary of the Earth Summit that took place in Rio de Janeiro in June 1992 to attempt to regain some of the momentum which has been lost since the meeting closed.

Up to 500 representatives of governments, environmental groups and the private sector will meet in Rio in the third week of March for an event called RIO+5 to review the successes and failures of the years since the 1992 summit.

Two months later, the general assembly of the United Nations is due to meet in special session to see what progress member states have made in implementing Agenda 21, the document they signed at Rio.

Maurice Strong, the Canadian industrialist and veteran environmentalist who served as secretary-general of the Earth Summit, said in Washington DC last week

that $\mathrm{RIO}+5$ is "designed to regenerate some of the momentum, which, to some degree, has faltered" since 1992.

According to Strong, although many good things have happened as a result of the Rio meeting, "the basic trends in our economic life which have caused the environmental problems have not changed, and the environment continues to deteriorate".

The track records of governments, particularly in developed countries, have come under attack in two reports published last week. One is produced by the Earth Council, an international pressure group which Strong chairs, and the other by the Worldwatch Institute, based in Washington.

The environmentalists argue that Rio has had some positive impact, pushing some governments and corporations to listen to green arguments at various forums established since the summit, and to incor-

\section{Industrial apathy 'hampers climate schemes'}

[NEW DEHH] The prospects of slowing down climate change through a scheme in which industrialized countries sponsor the reduction of greenhouse gas emissions in the developing world appear to be receding. That was the conclusion of a meeting organized by developing countries in New Delhi last week.

Representatives of 150 countries agreed that idea of 'joint implementation' is sound, but reported slow progress. Only 30 projects have been approved since the pilot phase was launched two years ago

Joint implementation was promoted at the 1992 Earth Summit (see above). The idea seemed attractive, as it offers advantages to both developing and industrialized countries.

Greenhouse gas emissions from industrializing countries are likely to rise sharply in the next decade. Under joint implementation, developed countries transfer low-cost energy-efficient technologies to the developing world.

Developing countries saw an opportunity to obtain private capital to finance new technologies. In return, credit for energy saved is passed on to developed countries as part of their greenhouse gas reduction targets.

The terms under which such a strategy would work have yet to established. But parties to the UN climate convention had hoped that these issues would be resolved during the pilot phase of carbon-reducing activities implemented jointly.

"It is a matter of concern, given that most of the projects have not reached the operational phase," according to a statement agreed by participants at the conference.

A consensus emerged at the conference that the 2000 deadline for evaluating the pilot phase is too close, and that information about projects is unlikely "to serve as a credible basis for a decision on whether to move forward". Some felt that the pilot phase may have to be extended by five or ten years.

The lack of pilot projects is also being attributed to industrial apathy. The conference heard that neither new technologies nor private investment for project finance have materialized.
The prospect of significant participation from business remains remote, particularly as investment in carbon-reducing projects is unlikely to yield significant returns. "[A pilot] project is like an $R \& D$ project, and it has potential to get profit in future," says Hidehisa Tanaka of Mitsubishi Research Institute of Japan. In his view, companies will not participate unless projects "are formulated from a commercial base and some incentives are provided".

The pilot phase is also the victim of a lack of trust between developed and developing countries. A delegate from Zimbabwe pointed to "a tendency of the investor countries to target host locations where they can maximize commercial profits".

But Ashok Khosla, who organized the conference on behalf of Development Alternatives, an Indian nongovernmental organization, believes that "all hope is not lost", as many potential pilot projects may be converted into actual projects in the three years before the pilot phase comes up for review.

K.S.Jayaraman porate some of the issues raised in their decision-making.

Strong cites the setting up of more than a hundred national councils for sustainable development as one of Rio's principal achievements, although conceding that their performance has been "mixed". He also says that some 1,500 cities across the world have set up committees to monitor local compliance with Agenda 21.

Environmentalists claim that the developed countries have failed to live up to promises made in Rio. The United States, for example, has failed to ratify the Biodiversity Treaty, cut back on aid that developing countries said they would need to comply with Agenda 21, and is unlikely to meet the Rio goal of stabilizing emissions of greenhouse gases at 1990 levels by the end of the decade.

Strong was restrained in his criticism of the governments of these countries, arguing that the public had to support painful changes, such as higher fuel prices, before such changes could be implemented. "Even Canadians won't accept increases in energy prices," he concedes. "I am frustrated, but the moment you give up, your pessimism will become self-fulfilling."

Jonathan Lash, president of the World Resources Institute (another Washingtonbased environmental group) and co-chair of the President's Council for Sustainable Development in the United States, says that despite its obvious failings, Rio has achieved a notable list of successes.

The summit established the environment as "an important part of the dialogue of international leaders" for the first time, he says. It had encouraged the private sector to take environmental issues seriously, and environmentalists to consider economics and human needs in their campaigns. And the summit confirmed the establishment of a new source of development funds, the Global Environmental Facility (see Nature 385,106 ; 1997).

But as the Earth Council points out in its report, the major problems addressed at Rio have continued to fester. The council points out that carbon dioxide emissions have grown in developed and developing countries, while deforestation and biodiversity losses continue apace.

The Worldwatch Institute's annual State of the World review says that, in its scale and scope, the summit "set a standard for itself that was almost certain to lead to disappointment". It calls for the establishment of an "E8" of the countries that "shape global environmental trends" - China, the United States, Brazil, Germany, Japan, India, Indonesia and Russia - to "catalyse action" on the environment, along the lines of the G7 group of capitalist economies. 